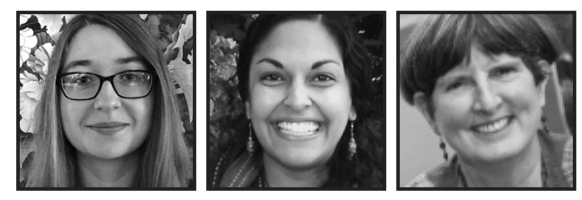

\title{
Undocumented Migrants, Rights Literacy, and ESOL Classrooms: A Community-University Partnership to Enhance Psychopolitical Learning
}

Gloria McGillen, Sriya Bhattacharyya, and M. Brinton Lykes, Boston College

\section{ABSTRACT}

This article presents the English for Speakers of Other Languages (ESOL) Know Your Rights Tool Kit, a popular education resource developed collaboratively by action researchers, ESOL instructors, and undocumented migrant adults. The tool kit draws on migrant learners' commitments to learning English while facilitating their developing knowledge of human and legal rights literacy information. The article situates resources engaged in ESOL classrooms within a psychopolitical educational framework (Prilleltensky, 2008) and discusses the tool kit's contributions towards bolstering these resources. It concludes with next steps for the tool kit, focusing upon its potential to foster action and advocacy within migrant communities.

uring the past three decades, laws and policies targeting migrant
communities have resulted in the deportation of millions of individuals
from the United States, 1.3 million between 2012 and 2015 alone (U.S. Immigration and Customs Enforcement, 2015). Migrants face numerous additional challenges, including restrictions in access to healthcare, housing, higher education, and employment based upon their legal status (Abrego, 2011). Monolingual ideologies and practices in the U.S. (Wiley, 2000)' further limit access to valued resources among migrants with limited English proficiency and are used to justify oppressive and illegal practices perpetrated against them by the state and other actors (Bacallao \& Smokowski, 2013; Dávila, 2008; Piller \& Takahashi, 2011). 
Limited English proficient (LEP) is a term that is used in the U.S. to describe individuals who do not speak English as their primary language and who have limited ability to communicate in or understand English (Sharpton, 2012). This status can intensify threats that migrants experience by restricting their capacity to resist or avoid them, such as their capacity to organize with monolingual English-speaking workers (Heyes, 2009; Holgate, 2011). Altogether, given these significant challenges, demand for English for Speakers of Other Languages (ESOL) instruction as a supplement to family-based language support among LEP migrant adults is unsurprising (Lykes et al., 2016; Martin \& Daiute, 2013). The responsiveness of traditional ESOL instruction to the legal and social challenges undocumented migrants face, however, remains low (Cooke, 2006).

The ESOL industry has been widely criticized for producing instructional materials that misrepresent the social and political context of learners' lives and fail to equip them for negotiating daily challenges they encounter (Candlin, 2001). Sociologists and applied linguists have observed hidden curricula within mainstream ESOL resources that privilege individual and market-driven solutions to social problems over collective solutions and political action (Auerbach \& Burgess, 1985; Block, Gray, \& Holborow, 2012; Cooke, 2006; Gulliver, 2010). Scholars and educators concerned about individualist and nativist biases in ESOL programming have critiqued these resources for serving the needs of industry and the state over those of migrant learners and their communities (Auerbach, 1986; Giroir, 2014; Tollefson, 1986). For example, civic literacy curricula teach established pathways to U.S. citizenship (Center for Adult English Language Acquisition, 2010; Griswold, 2010), but neglect prominent critiques of U.S. immigration policies and the specific interests of undocumented learners who are ineligible for resident status under the current U.S. immigration system. Auerbach (1986) and Tollefson (1986) similarly critique ESOL "survival curricula" for emphasizing low-paid work and worker compliance over labor organizing and a full spectrum of employment opportunities.

Recognizing the social and psychological impact of such instruction upon learners, and responding to calls from migrant communities for more representative programming, some scholars and practitioners have developed alternative curricula that foreground adult migrants' diversity and self-identified challenges and needs. Participatory and problem-solving approaches in ESOL (e.g., Auerbach, 1992; Auerbach \& Wallerstein, 1987; Baynham, 1988) invite students to analyze and work to change their social conditions. Critical approaches (e.g., Auerbach, 1992; Auerbach \& Wallerstein, 1987; Ullman, 1999) use elements of critical theory to help learners observe and name dynamics of social oppression and to develop resources to work against these forces (Simpson \& Whiteside, 2012). 
To build upon these alternative resources, and to address a desire in migrant communities for greater access to "Know Your Rights" (KYR) training (Lykes, McDonald, \& Boc, 2012), the interdisciplinary Migration and Human Rights Project (MHRP) at Boston College's Center for Human Rights and International Justice (CHRIJ), alongside several partner migrant organizations, decided to develop the English for Speakers of Other Languages (ESOL) Know Your Rights Tool Kit, a popular education resource through which undocumented migrants can learn English and develop knowledge and skills to address some of the specific social and legal challenges they face while residing in the U.S without proper legal authorization. For nearly a decade prior to the development of the tool kit, the Boston College MHRP facilitated "Know Your Rights" workshops with New England-based migrants and their transnational and mixed-status families, within a multi-year participatory action research process (Lykes et al., 2012). These workshops served as a foundation for the resource. The resulting ESOL Know Your Rights Tool Kit is currently composed of four units: 1) Basic Human Rights, 2) Knowing Your Rights in a Car Stop, 3) Protecting Families in Cases of Separation, and 4) Understanding the U.S. School System. Each unit is appropriate for intermediate-level ESOL classes, and the former two also include versions for beginners. Units feature multiple, independent lessons with corresponding teacher's guides, student handouts, and frequently asked legal questions (FAQ) sheets. The project is ongoing, with plans to add units as needs are identified, to update legal FAQ sheets if and when laws change, and to incorporate feedback that is being systematically collected from current and past users. All units are free and publicly available for download on the CHRIJ website (Boston College Center for Human Rights and International Justice, 2016; http://www.bc.edu/centers/humanrights/resources/esol-kyr-toolkit.html).

In this article, we discuss sample resources from the tool kit and present observations from the piloting process that illustrate how student learners and their instructors perceived the tool kit, with a particular focus on feedback that described its contributions to enhancing undocumented adult learners' psychosocial resources, and to supporting them in responding to the linguistic and legal challenges they face in the U.S. To analyze learners' and instructors' interactions with both the tool kit's popular education framework and its rights literacy content, we draw on community psychologist Isaac Prilleltensky's (2003; 2005; 2008) model of psychopolitical education. Psychopolitical education focuses upon the political sources and operations of power that generate diminished quality of life among oppressed and marginalized groups. Prilleltensky (2003) identifies the denial of rights and insecurity and exploitation, including legal threats, as central experiences 
of collective oppression. These issues as they affect undocumented migrants are the focus of the ESOL Know Your Rights Tool Kit.

Psychopolitical education engages learners in 10 key actions toward personal and community-based liberation, five of which align closely with psychosocial resources fostered in ESOL classrooms and targeted for enhancement by the tool kit (Table I). Below, we discuss these resources-rights literacy and legal consciousness, positive identity development, social support, and community-building-as they were illustrated during the piloting of the tool kit. We also consider the tool kit's potential to foster activism and advocacy within the communities of undocumented migrants and those of their instructors, additional actions toward psychopolitical well-being explored within Prilleltensky's (2003) model. We conclude with a discussion of the strengths and limitations of the tool kit, based upon learner and instructor feedback, as well as the project's contribution toward enriching ESOL instruction as a resource to promote "bottom-up" movements for the defense of undocumented migrants' rights and well-being.

\section{Table 1}

\section{Comparison of Resources for Psychopolitical Well-Being}

PRILLELTENSKY (2003): MODEL FOR UNDERSTANDING, RESISTING, AND OVERCOMING OPPRESSION

ACTIONS TOWARD LIBERATION
BOSTON COLLEGE MHRP: THE ESOL KNOW YOUR RIGHTS TOOL KIT

PSYCHOSOCIAL RESOURCES ENRICHED BY THE TOOL KIT

\begin{tabular}{|l|l|}
\hline $\begin{array}{l}\text { 1. Prevent exclusion and promote } \\
\text { liberation through education }\end{array}$ & $\begin{array}{l}\text { 1. Rights literacy and legal } \\
\text { consciousness }\end{array}$ \\
\hline \begin{tabular}{l} 
2. $\begin{array}{l}\text { [Develop] assertiveness and positive } \\
\text { self and cultural image }\end{array}$ \\
\hline $\begin{array}{l}\text { 3. Join networks of support that focus } \\
\text { on personal, relational, and collective } \\
\text { well-being }\end{array}$
\end{tabular} & $\begin{array}{l}\text { 3. Social support } \\
\text { identity development }\end{array}$ \\
\hline $\begin{array}{l}\text { 4. Build trust, connections, and } \\
\text { participation in groups }\end{array}$ & 4. Community-building \\
\hline $\begin{array}{l}\text { 5. Join social action groups that work } \\
\text { to enhance personal empowerment } \\
\text { and solidarity at the same time }\end{array}$ & 5. Social advocacy and activism \\
\hline
\end{tabular}




\section{Piloting the Tool Kit With ESOL Migrant Communities}

Three piloting sessions were held during the development of the tool kit. At each session, three lessons from the units were introduced. Participants included community-based instructors, university students from the MHRP, and adult migrant ESOL students. Prior to piloting the lessons, MHRP members met with the instructors to review the lesson plans and objectives, and to discuss the tool kit's rights literacy content. The piloting involved instructors conducting the lessons while university MHRP students were in the room to support and take notes geared toward collaboratively revising the resource. Immediately after piloting, the experience and the tool kit's strengths and limitations were debriefed, and revision decisions were discussed.

Throughout the pilot, instructors and learners engaged in activities informed by the perspective and techniques of popular education. Popular education is an approach to teaching and learning that is grounded in participants' lived experiences and that aims to equip them for engaging in collective, community-based actions (Beder, 1996; Freire, 1985; 1990). Its central pedagogical techniques, problem posing and consciousness-raising, invite learners to reflect upon and critically analyze the realities of their daily lives. Through this process, learners and instructors identify what Freire (1990) referred to as "generative themes," the collective issues or problems most important to the group. In learning contexts guided by theories of popular education, these themes form the basis of reflection and learner action-planning focused upon political and/or social change (Association for Community-Based Education, 1988). Historically, popular education is an approach that has been directed at work with communities experiencing marginalization and oppression (Freire, 1990; Hope \& Timmel, 1984), including documented and undocumented migrants (Cho, Paz y Puente, Yoon Louie, \& Khokha, 2004), making it well-suited to the context of the adult ESOL classroom.

\section{Rights Literacy and Legal Consciousness}

A unique strength of the ESOL Know Your Rights Tool Kit is its incorporation of legal and rights literacy information of interest to members of undocumented migrant communities (Lykes et al., 2012). Topics addressed by the curriculum and explored during the community pilot include basic human rights, individual rights in car stops, parental rights in cases of family separation (e.g., immigration detention or deportation), and the rights of students and their parents or guardians within the U.S. public school system. Through the tool kit's popular education framework, 
participants engaged in activities concerning these topics and collectively evaluated, contested, and made meaning of international human rights standards and their relevance to their immediate situations. They also explored whether and how U.S. law and policy guarantee or violate their rights.

Migrants, particularly those who are undocumented, have suffered a marked increase in legal and human rights violations in the U.S. in the post-9/11 era (Kanstroom, 2008; Lykes et al., 2012). Discrimination related to migrants' legal status constitutes a significant individual- and community-level stressor (Inman \& Tummala-Narra, 2014). Some scholars also conceptualize this threat as a form of violence, given the resultant material, social, and psychological harm to migrants (e.g., Menjívar \& Abrego, 2012). Minimally, it is a threat to their well-being (Brabeck, Lykes, \& Hunter, 2014). Education and capacity-building among migrants in defense of their rights is therefore of paramount importance (Abrego, 2008; Gates, 2011).

In Unit 1, learners discuss the concept of human rights as it pertains to their lives. They connected by sharing human rights violations they witnessed or experienced in their home countries, such as lack of food or healthcare, and also discussed feeling surprised that their human rights are not consistently observed in the U.S. Unit 2 of the tool kit facilitated learners' expression of the importance of knowing their right to remain silent during a car stop. In the lesson, they role-played scenarios of how they would respond to a police officer in a car stop situation. According to debriefing sessions with instructors, these activities helped learners and instructors deepen their understandings of the law from their particular social locations, a form of awareness sometimes referred to as legal consciousness (Abrego, 2011; Merry, 1990).

\section{Individual and Collective Identity Development}

Political action, such as claiming one's rights, is facilitated and sustained by a sense of collective and individual identity (Abrego, 2008; Wright, Taylor, \& Moghaddam, 1990). Among undocumented migrants, as well as other oppressed and marginalized groups, social distortions of one's self-image and group identity are associated with reduced self-esteem and impaired psychological functioning (Suárez-Orozco, 2000). The ESOL industry is profoundly restrictive, however, and all too frequently perpetuates educational processes that negatively affect undocumented migrants' identity (Candlin, 2001) - by suggesting that they adapt to stereotypes such as "being Latino," for example, while limiting their work aspirations to low-income jobs avoided by most citizens (Auerbach, 1986; Tollefson, 1986). 
To counteract the effects of these processes, the ESOL Know Your Rights Tool Kit emphasizes the use of personal experience for collective reflection and creative action, and expands opportunity for undocumented learners to incorporate their cultural backgrounds and unique social vantage points into the learning process. In the example of Unit 3 of the tool kit, "Protecting Families in Cases of Separation," learners discuss parental rights and how they may be observed or restricted when a parent is an undocumented migrant. During the pilot, learners practiced affirming their parental rights and family dignity by completing and sharing a poem entitled, "We Are a Family," an activity that concludes with an assertion of family rights. In the pilot of Unit 2, introduced above, learners were asked to create a dialogue in which they asserted their right to remain silent during a police traffic stop. Through this theater activity and ensuing class discussion, learners explored their identities as rights-bearing subjects in the U.S., while many also articulated threats and limitations to this status.

\section{Social Support}

Social support is a highly valued element of the ESOL classroom experience among migrant learners, many of whom are otherwise socially and linguistically isolated (Bacallao \& Smokowski, 2013; Cooke, 2006). The ESOL Know Your Rights Tool Kit is designed to enhance exchange of social support. Interviews with ESOL learners and instructors suggest that peers in courses are valued for their ability to offer linguistic connection, empathic understanding, material support, and strategies for living (Cooke, 2006; Dávila, 2008; Gates, 2011). Such strategies may include suggestions about how to access community resources, or to mitigate or resist the effects of interpersonal and institutional discrimination. Instructors and conversation partners also offer learners casual contact with native or advanced speakers of English, a resource limited in many adult migrants' daily lives (Cooke, 2006; Dávila, 2008; Lykes et al., 2016).

The ESOL Know Your Rights Tool Kit bolsters these processes through activities including sociodrama and group discussion, which invite learners to share personal knowledge and learn from the experiences of their peers and instructors. In Unit 4, for example, "Understanding the U.S. School System," learners review stories about two children receiving English as a Second Language (ESL) and special education services in U.S. public schools. While completing these activities during the pilot, learners shared their own stories about their children and other young family members attempting to access such services in their communities. 
Some emphasized the importance of family advocacy in this process, and knowing the student's rights - especially when the child was high school-aged or had more intensive instructional needs, and was thus more likely to be denied appropriate support due to limitations in a school's resources. These moments of collective reflection welcomed expressions of mutual understanding and the exchange of local knowledge about which schools in the surrounding communities were relatively well resourced.

\section{Community-Building}

Many educators and researchers working with adult migrant learners have observed the capacity of ESOL classrooms to function as sites for creating or developing community (e.g., Malsbary, 2014; Prins, Toso, \& Schafft, 2009; Stern, 1997; Ullman, 1999). The ESOL Know Your Rights Tool Kit is intended to enhance community-building processes within the ESOL classroom and beyond it. Community is a long-debated concept in critical and community psychology (Loomis, 2014), and migrant groups and those who work with them similarly contest the idea (Cooke, 2006). Popular depictions of urban migrant neighborhoods often obscure heterogeneity, social divisions, and strained social networks among this population (Block, 2006; Stern, 1997). Acknowledging these limitations of the concept, in this discussion we endorse Loomis' (2014) definition of community as individuals associated by location, relationship, or power "enhanc[ing] their quality of life by working together to solve individual and group problems" (p. 277). We view community thus defined as a valuable and desired resource for migrants, whose meaning is sharpened by the geographic and social dislocations with which this population contends.

The tool kit was designed to function as a community-building resource through its emphasis on collective identity development and exchange of social support, in an environment in which undocumented adult migrant learners are encouraged to explore unique and often marginalized aspects of their daily experience. In response to activities concerning human rights introduced during the pilot of Unit 1, a group of learners from Columbia, Brazil, and El Salvador entered into conversation about discrimination they face in the U.S. One reflected at the end of the discussion, "Ya nos desahogamos" ("We released our pains"). These learners appreciated having a space to talk about their rights as migrants and demonstrated feelings of solidarity with one another regarding their shared hardships. Similarly, learners who participated in the pilot of Unit 4 expressed that they appreciated speaking together as parents and loved ones of school-aged youth navigating the U.S. public school system. One concluded that, 
although schools in the U.S. sometimes fail to support LEP migrant families, these families and others in the community can help one another protect their children's right to high-quality education.

\section{Social Advocacy and Community Action}

A final intended outcome of the resources promoted by the ESOL Know Your Rights Tool Kit_-rights literacy and legal consciousness, positive identity development, social support, and community-building-is adult migrant learners' and their instructors' deepening engagement with social advocacy and community action. This objective acknowledges the current intransigence of the U.S. Congress and its lawmakers in advancing comprehensive immigration reform, and the need for alternative strategies towards political change. Additionally, it reflects our deep respect for and participation in social movements formed and led by migrant populations in the U.S. (e.g., ongoing immigration reform, migrant labor, and counter-globalization movements), as well as our recognition of the urgent need to eliminate the many threats and forms of violence this population experiences under contemporary global and domestic conditions (Menjívar \& Abrego, 2012).

Historically, adult education in the U.S., including adult English language instruction, emerged from intellectual and political traditions that encouraged learners toward political action, viewing politics as a legitimate topic of classroom concern and instruction (Heaney, 1996). While material and social circumstances surrounding the field of adult education have widely undercut its socially progressive and radical roots, they remain influential in some classrooms and have more recently been bolstered by developments in popular education, feminism, post-colonialism, and other intellectual and social movements (English \& Mayo, 2012; Heaney, 1996; Youngman, 2000). ESOL resources aimed toward political action - and the visions and methods of change encouraged by them-vary widely. We view the ESOL Know Your Rights Tool Kit as a contribution to this tradition.

Concretely, the tool kit, in a range of lessons within its current four-unit structure, exposes students to examples of protest and other forms of public engagement of social issues, as well as the defense of individual and family rights through professional legal consultation and self- and collective advocacy. In Unit 2, for example, learners read and reflect upon the story of Mariola Perez, an undocumented migrant from Guatemala who received a stay of deportation and was released from the custody of U.S. Immigration and Customs Enforcement (ICE) after a successful community advocacy campaign conducted on her behalf and that of her three-year-old son. 
Throughout the piloting of the four units, learners and instructors periodically remarked that it is important to draw on collective and community resources to defend the rights of undocumented migrants. In one representative exchange, learners participating in the pilot of Unit 1, regarding human rights, pointed out that these rights are sometimes violated by undocumented migrants' employers, who subject them to exploitation, including, for example, non-payment of overtime wages, knowing that they are unlikely to be prosecuted for such abuses. Instructors affirmed the reality of these problems and named several local organizations workings with migrants and other community members to challenge labor abuses, through marches, protests, and educating others about their workplace rights. Learners and instructors also consistently discussed the importance of becoming knowledgeable about legal resources in the community, in preparation for potential interactions with police and the possibility of entering immigration detention. In addition to these examples, which demonstrate the power of the tool kit to foster awareness of community resources and the importance of advocacy and community action, we recognize that the exchange of social support and language learning themselves are infused with political meaning (Malsbary, 2014; Simpson \& Whiteside, 2012). When engaged by adult migrants and other learners who experience oppression, they hold socially transformative potential.

\section{Concluding Reflections and Next Steps}

The ESOL Know Your Rights Tool Kit is a resource for English language and psychopolitical learning that promotes community-based advocacy and action. It is an iterative and dynamic work in progress consisting of four units that will grow and change alongside the movement for migrant rights and comprehensive immigration reform in the U.S.

Through partnership with groups of community-based ESOL instructors and adult migrant learners to develop and pilot the tool kit, we have begun to explore how this resource can enhance processes of psychopolitical learning nurtured in ESOL classrooms, and how it can support and, in some cases, serve as a catalyst for learners' and instructors' involvement in advocacy and community action in support of undocumented migrants. Feedback and observations from the piloting process affirmed the value of these resources to undocumented learners in the face of the pervasive challenges they experience, while they also highlighted complexity and risk associated with these defenses of one's own and one's family's and 
community's interests under current U.S. practices of detention and deportation. While acknowledging the critical role of advocacy and community action towards achieving better living and working conditions, discussions facilitated by the tool kit created spaces in which undocumented learners could express anxiety and fear of being detained or deported that they and their families experience.

Similarly, the feedback of instructors involved in the pilot highlighted unique strengths of the tool kit when contrasted with traditional ESOL instructional resources, most of which are silent on the issue of undocumented migrants. Instructors also addressed practical challenges to implementing the tool kit in the classroom, and expressed the necessity of deepening their understanding of legal challenges and processes affecting undocumented migrants in order to implement it most effectively. Further, they remarked on the sometimes speculative and openended nature of discussions of legal topics among learners. In response to these dynamics, both instructors and learners expressed the importance of seeking support beyond the classroom and in the community in conjunction with using the tool kit. Thus, the ESOL Know Your Rights Tool Kit emerged as a foundation or starting point in a broader process of self- and community-education, advocacy, and action-taking to promote the well-being of undocumented migrants and the protection of their rights.

The tool kit is one exemplar of how community-based ESOL instructors and university-based action researchers can partner with migrants to develop participatory resources that teach English while also enhancing psychopolitical learning among both ESOL instructors and learners. This community-university partnership is an ongoing site for exploration of how ESOL education can contribute to "bottom up" migrant-led movements for social and political change. Systematic research into the use and possible effects of the tool kit on migrants and their organizations is just beginning. Our hope is that those who employ this resource for ESOL instruction will use it to accompany undocumented migrant learners living in the U.S. in their efforts toward psychopolitical well-being, and their search for and struggle towards a more just community for us all.

\section{Acknowledgments}

The authors would like to thank, first and foremost, the many undocumented migrants in New England, as well as the staff of Women Encouraging Empowerment, Casa (now Casita) El Salvador, and Centro Presente, who graciously gave of their 
time and resources for the development of the ESOL Know Your Rights Tool Kit. We also acknowledge the generous support of the Center for Human Rights and International Justice and of the undergraduate and graduate students on the Migration and Human Rights Research Team, RADICALeS, who collaborated in the tool kit's development and implementation. Our particular thanks to Rocío Sánchez Ares, Peter LaMear, and Jessica Chicco.

\section{Note}

1. Despite the fact that most people in the world are multilingual (Edwards, 2002), monolingualism is treated in many Western societies as a norm (Ellis, 2006; Romaine, 1989). Only $21 \%$ of the U.S. population reports speaking a language other than English at home (Ryan, 2013).

\section{References}

Abrego, L. (2008). Legitimacy, social identity, and the mobilization of law: The effects of Assembly Bill 540 on undocumented students in California. Law \& Social Inquiry, 33(3), 709-734. doi:10.1111/j.1747-4469.2008.00119.x

Abrego, L. J. (2011). Legal consciousness of undocumented Latinos: Fear and stigma as barriers to claims making for first and 1.5 generation immigrants. Law \& Society Review, 45(2), 337-370. doi:10.1111/j.1540-5893.2011.00435.x

Association for Community-Based Education. (1988). Literacy for empowerment: A resource handbook for adult educators. Washington, DC: Author.

Auerbach, E. R. (1986). Competency-based ESL: One step forward or two steps back? TESOL Quarterly, 20(3), 411-429. doi:10.2307/3586292

Auerbach, E. R. (1992). Making meaning, making change. Participatory curriculum development for adult ESL literacy. Washington, DC: Center for Applied Linguistics. Retrieved from ERIC database. (ED356688)
Auerbach, E. R., \& Burgess, D. (1985). The hidden curriculum of survival ESL. TESOL Quarterly, 19(3), 475-495. doi:10.2307/3586274

Auerbach, E. R., \& Wallerstein, N. (1987). English for the workplace: ESL for action: problem posingatwork. Reading, MA:Addison-Wesley.

Bacallao, M.L., \&Smokowski, P.R. (2013). Obstacles to getting ahead: How assimilation mechanisms impact undocumented Mexican immigrant families. Social Work in Public Health, 28(1), 1-20. doi:10.1080/19371910903269687

Baynham, M. (1988). Action and reflection: The Freirean argument in ESL. Language Issues, $12,6-12$.

Beder, H. (1996). Popular education: An appropriate educational strategy for communitybased organizations. New Directions for Adult and Continuing Education, 1996(70), 73-83. doi:10.1002/ace.36719967009

Block, D. (2006). Multilingual identities in a global city: London stories. Palgrave Macmillan. doi:10.1057/9780230501393 
Block, D., Gray, J., \& Holborow, M. (2012). Neoliberalism and applied linguistics. London: Routledge.

Boston College Center for Human Rights and International Justice. (2016, April 2). Know Your Rights - English for Speakers of Other Languages Tool Kit. Retrieved from http://www.bc.edu/centers/humanrights/ resources/esol-kyr-toolkit.html

Brabeck, K., Lykes, M.B., \& Hunter, C. (2014). The psychosocial impact of detention and deportation on US migrant children and families. American Journal of Orthopsychiatry, 84(5), 496-505. doi:10.1037/ort0000011

Candlin, C. (2001). General editor's preface. In M. Breen (Ed.), Learner contributions to language learning: New directions in research (pp. xv-xxii). London: Routledge.

Center for Adult English Language Acquisition. (2010). Education for adult English language learners in the United States: Trends, research, and promising practices. Washington, D.C.: Author. Retrieved from http://www.cal.org/ caelanetwork/pdfs/education-for-adultells-with-new-copyright.pdf

Cho, E.H., Paz y Puente, F.A., Yoon Louie, M.C., \& Khokha, S. (2004). BRIDGE: Building a race and immigration dialogue in the global economy. Oakland, CA: National Network for Immigrant and Refugee Rights.

Cooke, M. (2006). "When I wake up I dream of electricity": The lives, aspirations and 'needs' of adult ESOL learners. Linguistics and Education, 17(1), 56-73. doi:10.1016/j. linged.2006.08.010

Dávila, L. T. (2008). Language and opportunity in the "land of opportunity": Latina immigrants' reflections on language learning and professional mobility. Journal of Hispanic Higher Education, 7(4), 356-370. doi:10.1177/1538192708321652

Edwards, J. (2002). Multilingualism. London: Routledge.

Ellis, E. (2006). Monolingualism: The unmarked case. Estudios de Sociolingüística: Linguas, Sociedades e Culturas, 7(2), 173-196. doi:10.1558/sols.v7i2.173
English, L. M., \& Mayo, P. (2012). Learning with adults: A critical pedagogical introduction. Rotterdam: Sense.

Freire, P. (1985). The politics of education: Culture, power, and liberation. South Hadley, MA: Bergin \& Garvey.

Freire, P. (1990). Pedagogy of the oppressed. New York: Continuum.

Gates, A. B. (2011). Narrowing the citizenship gap for undocumented immigrants: A case study of the Mid-Michigan Worker Center. (Doctoral dissertation). Retrieved from Deep Blue at the University of Michigan.

Giroir, S. (2014). Narratives of participation, identity, and positionality: Two cases of Saudi learners of English in the United States. TESOL Quarterly, 48(1), 34-56. doi:10.1002/ tesq.95

Griswold, O. (2010). Narrating America: Socializing adult ESL learners into idealized views of the United States during citizenship preparation classes. TESOL Quarterly, 44(3), 488-516. doi:10.5054/tq.2010.226855

Gulliver, T. (2010). Immigrant success stories in ESL textbooks. TESOL Quarterly, 44(4), 725-745. doi:10.5054/tq.2010.235994

Heaney, T. (1996). Adult education for social change: From center stage to the wings and back again. Washington, DC: Office of Educational Research and Improvement. Retrieved from ERIC database. (ED396190)

Heyes, J. (2009). Recruiting and organising migrant workers through education and training: A comparison of Community and the GMB. Industrial Relations Journal, 40(3), 182-197. doi:10.1111/j.1468-2338.2009. 00520.x

Holgate, J. (2011). Temporary migrant workers and labor organization. Working USA, 14, 191199. doi:10.1111/j.1743-4580.2011.00332.x

Hope, A., \& Timmel, S. (1984). Training for transformation: A handbook for community workers. Gweru, Zimbabwe: Mambo Press.

Inman, A. G., \& Tummala-Narra, P. (2014). Immigration and human rights. In M. L. Miville \& A. D. Ferguson (Eds.), Handbook of race-ethnicity and gender in psychology (pp. 87-109). New York: Springer. 
Kanstroom, D. (2008). Deportation nation: Outsiders in American history. Cambridge, MA: Harvard University Press.

Loomis, C. (2014). Community, overview. In T. Teo (Ed.), Encyclopedia of critical psychology (pp. 276-280). New York: Springer

Lykes, M. B., McDonald, E., \& Boc, C. (2012). The post-deportation human rights project: Participatory action research with Maya transnational families. Practicing Anthropology, 34(1), 22-26. doi:10.17730/ praa.34.1.I20501884743h62t

Lykes, M. B., Alvarez, E., Biano, E. M., Bravo, D., Fatty, F., Ferreira, K., et al. (2016). Migrant families and language: "...The person who speaks two languages has double the value". Boston: Center for Human Rights and International Justice, Boston College. Retrieved from http://www.bc.edu/centers/ humanrights/resources/migrant_families_ and_language.html

Malsbary, C. B. (2014). "It's not just learning English, it's learning other cultures": Belonging, power, and possibility in an immigrant contact zone. International Journal of Qualitative Studies in Education, 27(10), 1312-1336. doi:10.1080/09518398.201 3.837210

Martin, D., \& Daiute, C. (2013). English as a second language, a second chance, or second class membership: Exploring the costs and opportunities of Latina immigrants' narratives. Culture \& Psychology, 19(1), 117-138. doi:10.1177/1354067x12464983

Menjívar, C., \& Abrego, L. (2012). Legal violence: Immigration law and the lives of Central American immigrants. American Journal of Sociology, 117(5), 1380-1421. doi:10.1086/663575

Merry, S. E. (1990). Getting justice and getting even: Legal consciousness among working-class Americans. Chicago: University of Chicago.

Piller, I., \& Takahashi, K. (2011). Language, migration and human rights. In R. Wodak, B. Johnstone, \& P. Kerswill (Eds.), The SAGE handbook of sociolinguistics (pp. 583-597). London: Sage.
Prilleltensky, I. (2003). Understanding, resisting, and overcoming oppression: Toward psychopolitical validity. American Journal of Community Psychology, 31(1-2), 195-201. doi:10.1023/A:1023043108210

Prilleltensky, I. (2005). Promoting wellbeing: Time for a paradigm shift in health and human services. Scandinavian Journal of Public Health, 33, 53-60. doi:10.1080/14034950510033381

Prilleltensky, I. (2008). The role of power in wellness, oppression, and liberation: The promise of psychopolitical validity. Journal of Community Psychology, 36(2), 116-136. doi:10.1002/jcop.20225

Prins, E., Toso, B. W., \& Schafft, K. A. (2009). "It feels like a little family to me": Social interaction and support among women in adult education and family literacy. Adult Education Quarterly, 59(4), 335-352. doi:10.1177/0741713609331705

Romaine, S. (1989). Bilingualism. Oxford: Blackwell.

Ryan, C. (2013). Language use in the United States: 2011 American Community Survey reports. Washington, DC: U.S. Census Bureau. Retrieved from http://www.census.gov/ library/publications/2013/acs/acs-22.html.

Sharpton, A. N. (2012). Limited English proficiency. In S. Loue \& M. Sajatovic (Eds.), Encyclopedia of immigrant health (pp. 10161018). New York: Springer Science.

Simpson, J., \& Whiteside, A. (2012). Politics, policy and practice: ESOL in the UK and the USA. Working Papers in Urban Language \& Literacies, 78. Retrieved from http://www. $\mathrm{kcl}$.ac.uk/sspp/departments/education/ research/ldc/publications/workingpapers/ the-papers/WP87.pdf

Stern, H. (1997). Organizing ESL students for social change. (ERIC Document Reproduction Service No. ED408867).

Suárez-Orozco, C. (2000). Identities under siege: Immigration stress and social mirroring among the children of immigrants. In A.C. Robben \& M. Suárez-Orozco (Eds.), Cultures under siege: Collective violence and trauma (pp. 194-226). Cambridge, England: Cambridge University Press. 
Tollefson, J. W. (1986). Functional competencies in the U.S. refugee program: Theoretical and practical problems. TESOL Quarterly, 20(4), 649-664. doi:10.2307/3586516

Ullman, C. (1999). Between discourse and practice: Immigrant rights, curriculum development, and ESL teacher education. TESOL Quarterly, 33(3), 513-528. doi:10.2307/3587677

U.S. Immigration and Customs Enforcement. (2015, December 22). FY 2015 ICE immigration removals. Retrieved from https://www.ice.gov/removal-statistics
Wiley, T. G. (2000). Continuity and change in the function of language ideologies in the United States. In T. Ricento (Ed.), Ideology, politics, and language policies: Focus on English (pp. 67-85). Amsterdam: Benjamins.

Wright, S. C., Taylor, D. M., \& Moghaddam, F. M. (1990). Responding to membership in a disadvantaged group: From acceptance to collective protest. Journal of Personality and Social Psychology, 58(6), 994-1003. doi:10.1037//0022-3514.58.6.994

Youngman, F. (2000). The political economy of adult education and development: Global perspectives on adult education and training. New York: St. Martin's Press.

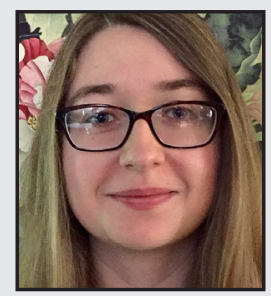

Gloria McGillen is a third-year master's student in counseling psychology and a researcher with the Center for Human Rights and International Justice at Boston College. Her work addresses the lifelong sociopolitical development of adults and youth, with a focus on undocumented migrants and other vulnerable workers living in the United States. She is currently a clinical trainee with Boston Public Schools.

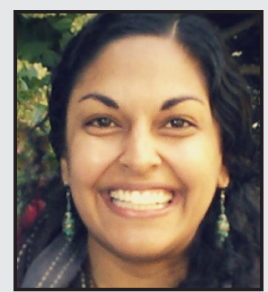

Sriya Bhattacharyya is a fifth-year doctoral student in counseling psychology at Boston College and a researcher at the Center for Human Rights and International Justice. Her work focuses on sociopolitical oppression and community-based strategies to combat it. She currently works at a community mental health center facilitating healing arts groups with women and girls from low-income communities, and she is a consultant at the Trauma Center at the Justice Resource Institute in their human trafficking program, Project Reach. 


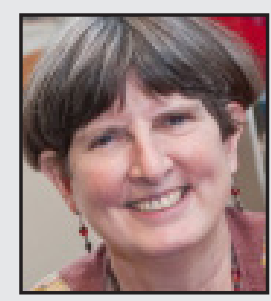

M. Brinton Lykes is Professor of Community-Cultural Psychology and Co-Director of the Center for Human Rights and International Justice at Boston College, USA. Her feminist participatory and action research collaborations include local cultural resources and the creative arts to analyze the causes and document the effects of gross violations of human rights. Her current work focuses on (1) racialized gender and sexual violence against Mayan women during armed conflict and their struggles for truth, justice, healing, and reparations; and, (2) migration and post-deportation human rights violations and their effects for transnational families. She is co-founder and/or a board member of several local and international NGOs. 